\title{
Day Times Kilogram per Milliliter
}

National Cancer Institute

\section{Source}

National Cancer Institute. Day Times Kilogram per Milliliter. NCI Thesaurus. Code C85585.

Days times kilograms per milliliter. 